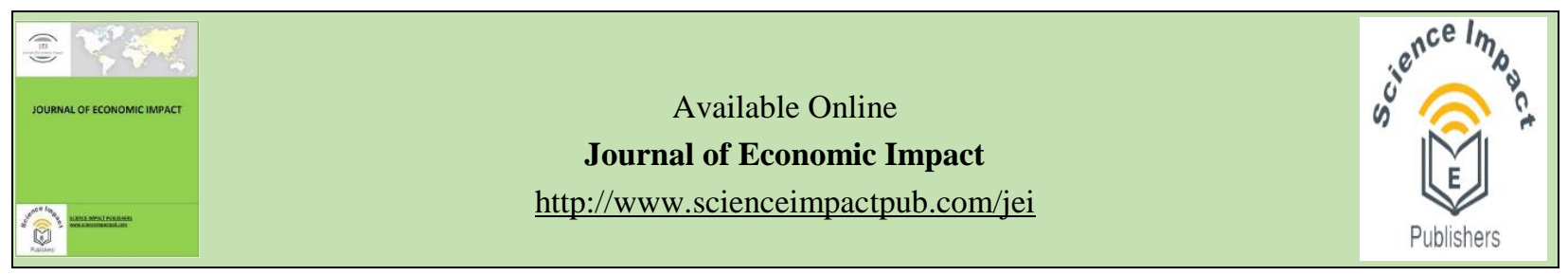

\title{
IMPACT OF BETTER MANAGEMENT PRACTICES ON SUSTAINABLE COTTON PRODUCTION: EVIDENCE FROM SOUTH PUNJAB
}

\author{
Tayyaba Hina*, Muhammad Asad ur Rehman Naseer \\ Institute of Agricultural and Resource Economics, University of Agriculture Faisalabad, Pakistan
}

\section{HIGHLIGHTS}

- The results of the study showed a positive impact of the education of farmers and farm size on BMPS adoption rate.

- The seed rate, fertilizer application and alternate/skip row irrigation had a positive impact on cotton yield per acre.

- The comparison of the cost of production by the adopter of sustainable agriculture practices and nonadopters shows that the total cost for non-adopter was greater than that of adopters.

- Adopters were in a better position to earn reasonable profits by following the BMPs.

\begin{abstract}
The basic purpose of this study was to look at the position of Better Management Practices (BMPs) of cotton crop in order to reduce the burden on our natural scarce resources. Relevant information was taken from 150 respondents from the district Khanewal, Punjab. The results of this study revealed that the education level and landholding size of respondents have a positive impact on the adoption of sustainable agricultural practices. While the farmer's age and farming experience were found a negative impact on BMPs adoption rate. Similarly, contact of respondents with the staff of farmer's field schools and the number of visits of farmer's field school staff were found positively correlated to BMPs adoption rate. The results of the regression analysis revealed the impact of different agriculture inputs and BMPs on cotton yield. The results showed that the age of the farmers, education, fertilizer, irrigations, water scouting, cotton area, farmyard manure, and hybrid seed variety and sowing method had a positive sign while the sign of pesticide coefficient was negative. The gross margins of BMPs adopter and non-adopter were 45,955 PKR and 28,790 PKR per acre respectively. The model also indicated that the production function fits well with the given data set. Therefore, the results of this study conveyed policy messages for the private and public organizations to promote BMPs for the betterment of the farming community.
\end{abstract}

Keywords: Better Management Practices (BMPs); cotton crop; sustainable production; Punjab-Pakistan.

Received: Oct 07, 2019; Accepted: Oct 22, 2019; Published: Oct 23, 2019.

* Correspondence: Institute of Agricultural and Resource Economics, University of Agriculture Faisalabad, Pakistan

Email: tayyaba_hina@outlook.com

\section{Introduction}

Better Management Practices (BMPs) are the tools for meeting today's farming goals. While minimizing the impact on the environment, an action must maintain or increase crop returns for BMPs. BMPs are practices used by agricultural producers to control the future generations and delivery of pollutants from agricultural activities to water resources of the state, and thus reduce the number of agricultural pollutants inflowing surface and ground waters, (Cassman and Pingali, 1995). Each BMP is a zenith of years of research and demonstrations conducted by soil engineers and agricultural research scientists. There is no one system for all farms. The combination of practices suitable for a farm will depend on individual problems and opportunities (Tilman et al., 2001). In recent years, the focus has broadened to include environmental factors in the crop production equation.

Cotton is among the five major crops of Pakistan and it contributes to national export earnings. However, the quality of cotton grown in Pakistan is not up to international standards (Naseer et al., 2019). International markets have an emerging demand for organic or better cotton (Awan et al., 2015). WWF-P is working on Pakistan Sustainable Cotton Initiative (PSCI) under the preferment of BMPs. Under the 
Better Cotton Initiative (BCI), the project has been amplified to meet the international standards of sustainable cotton production by adopting economies of scale for farmers and by achieving sustainable improvements in social-economic and human capital available for cotton crop. While using BMPs cost of production (Including social costs) is being reduced, resulting in an uplift of farmers' profit. In the short run, it is estimated that an amount of 3,450 PKR per acre has been saved while using BMPs in cotton production. It would offer many long-run benefits such as reduction of poverty, the sustainability of human capital, natural resources, and preservation of biodiversity (Abbas et al., 2017).

Environmental pollution is a threat to the biological systems of our globe. Agriculture contributes to environmental pollution because of the wild resource use in the production of crops and the rearing of livestock. Agriculture is one of the major causes of depletion of groundwater resources quickly as well as it affects the purity of ground and fresh water due to the excessive and improper use of chemicals such as fertilizers and pesticides for crop production (Abbas et al., 2017). The revolution of agricultural mechanization provided the ease and increased the efficiency level of production, but it also contributed to the air pollution due to the fuel consumption which adds to the greenhouse gases (Tilman et al., 2001).

Agriculture and the environment have interdependence. The degradation of the environment due to agriculture affects agriculture indirectly because of the change in the ecological system. The environmental pollutants affect the biological, ecological and environmental systems. Water, air and food pollution (due to greenhouse gases, chemical sprays, and fertilizers) leads to serious health hazards to both humans and animals, so the living cost of farming and non-farming community is increasing day by day due to the ultimate environmental degradation (Caswell et al., 2001).

Cotton cultivation leads to some serious social impacts and externalities. It is a water-loving crop, and its cultivation leads to water shortage problems in the areas where it is grown without crop diversification. Irrigation is crucial at different growth stages of the cotton crop to develop better lint quality (Clark et al., 2017). Cotton crop is host to many insects and pests, and to control this enormous amount of pesticides are used which are hazardous for the environment in the long run. According to reports and different studies about 8 to 10 percent of pesticides production is used on cotton crop only, and it raises the external social costs to about 12 billion rupees just by the pesticides (Zheng et al., 2016; Olayide et al., 2016). Child labor is another negative externality attached to cotton production and picking in less developed countries in
Asia especially India and Pakistan. Furthermore, the rapid increase in world population, unplanned and irrational use of scarce natural resources and inefficiency of farming practices and techniques creates a huge competition day by day among humans to survive (Sharma and Bajaj, 2010).

A number of studies have analysed the relationship in better management practices and economies of scale for different crops (Graham, 2006; Muhrely et al., 2009; Akudugu et al., 2012; Fanning et al., 2012; Awan et al., 2015). Keeping this in view, the analysis in this study is attempting to relate awareness about the use of BMPs and the economic impacts that will help policy managers to allocate limited resources more efficiently and productively.

\section{Materials and Methods}

\section{Empirical Analysis}

Gross margins of both sustainable cotton farmers and non-sustainable cotton farmers were calculated by partial budgeting technique which is simply a part of an enterprise budget, or crop rotation or farming system budget. The basic purpose of the technique in a nut crust is to organize experimental information in a way to help the manager to take a particular management decision like a choice of fertilizer and its quantity, variety choice, choice of seed rate and choices among alternative packages of such practices (Ahmad, 2001).

$$
\mathrm{GM}=\mathrm{TR}-\mathrm{TVC}
$$

Where

$\mathrm{GM}=$ Gross margin

$\mathrm{TM}=$ Total Revenue

$\mathrm{TVC}=$ Total variable costs

Variable costs (PKR/Acre) include pesticide, weedicide, fertilizer, irrigation, seed cost, land preparation cost, thinning cost, transportation, sowing cost, picking cost, hoeing, gap-filling cost and botanical alternatives for pesticide. And the fixed costs include land value, family labour (opportunity cost).

For data analysis, the Cobb Douglas production function was used. In agriculture production, the law of diminishing marginal returns holds, which means that agricultural output would decline after a certain limit of the inputs is continuously increased. So, the present study used Cobb Douglas production model to analyse the data. In a specific form, the equation can be written as;

$$
\mathrm{Yi}=\beta \mathrm{o} \text { Xi } \beta \mathrm{i} \mathrm{e} \mu
$$

It is a non-linear function, but it can be converted to a linear function after taking the natural log of both sides of equation (2). The log form of the equation with more than one input is written as: 


$$
\begin{aligned}
\ln Y= & \beta o+\beta_{1} \ln X_{1}+\beta_{2} \ln X_{2}+\beta_{3} \ln X_{3}+\beta_{4} \ln \\
& X_{4}+\beta_{5} \ln X_{5}+\beta_{6} D_{1}+\beta_{7} D_{2}+\beta_{8} D_{3}+\beta_{9} \\
& D_{4}+\mu
\end{aligned}
$$

Where "In" represents natural logarithm to base, "Yi" is equal to yield of cotton measured in $\mathrm{kg} / \mathrm{ha}, \mathrm{X} 1$ is equal to age (Years), $\mathrm{X} 2$ is equal to Education of respondent measured in years of schooling, $\mathrm{X} 3$ is equal to fertilizers use in kilograms/ha, $\mathrm{X} 4$ is equal to amount applied to hectare of cotton measured in pesticide measured in Grams/Litres and X5 is equal to Water applied to a hectare of cotton in Acre inches. D1 is equal to dummy for Hybrid Seed Varieties its value is equal to 1 if pesticide was used otherwise 0 , D2 is equal to dummy for water scouting its value is equal to 1 if water scouting was done otherwise 0 , D3 is equal to dummy for Farm Yard Manure its value is equal to 1 if hybrid varieties were sown otherwise 0 and D4 is equal to dummy for Sowing Method its value is equal to 1 if farmyard manure was used otherwise $0 . \mu$ is stochastic error term.

\section{Data Collection Procedure}

The study was carried out in district Khanewal, where WWF-P was popularizing the use of BMPs on a large scale. From Khanewal district of Punjab 150 farmers' primary data were collected among them 75 were Sustainable cotton producers and the other 75 were not. Cotton was chosen for analysis because cotton is major cash crop of Pakistan (GOP, 2014) and globally it is considered as one of the most inputintensive crops contributing in the use of plentiful irrigation water, fertilizer, pesticide, labor, etc. (Mohanty et al., 2003).

\section{Results and Discussion}

The average values of summary statistics for the relevant variables are presented in Table 1. The rate of adoption for BMPs was taken as the function of the socioeconomic variable, institutional variable, and environmental variable. It was observed that mean year of education, mean years of age, average landholding size and average farming experience of adopters were 9.34 years, 40.86 years, 24.02 acres and 14.1 years respectively. It was also noticed that mean year of education, mean years of age, average farm size and average farming experience of non-adopters were years 5.7 years, 42.47 years, 7.15 acres and 15.56 years respectively. Farm size is an important variable affecting the productivity and profitability of farmers (Naseer et al., 2016).

Table 1: Summary Statistics of Used Variables by Categories of Cotton Farmers

\begin{tabular}{lcc}
\hline Category & Adopters & Non-Adopters \\
\hline Age (Years) & 40.86 & 42.47 \\
Education (Years) & 9.34 & 5.7 \\
Farming Experience (Years) & 14.1 & 15.56 \\
Land Holding (Acres) & 24.02 & 7.15 \\
\hline
\end{tabular}

The age of the BMPs adopters was less than that for non-adopter that is in line with the previous study of Zhong (2008) and against with the opinion of Malik and Javed (2019) where age has a negative impact on income inequality by ineffective managerial decisions. While in psychological point of view age has a negative and insignificant impact on income of an individual (Mumtaz et al., 2019). There was a positive relationship between the rate of adoption of BMPs and the education level of farmers. Previous literature also concluded that educated farmers have a higher ability to adopt BMPs as compared to less educated people (Isgin et al., 2008; 2009; Deloitte and Tourche, 1992; Toma and Mathijs, 2007). BMPs adopters owned more areas for cultivation than the non-adopters. Our findings are in line with the results of Kouser et al. (2006) and Ghazalian et al. (2009) but these are contrary to the results of Byrnes et al. (1987). The farming experience of BMP adopters is significantly less than non- adopters because it relates to the age of farmer and our results are consistent with the findings of Muhrely et al. (2009).

The comparison was made based on agriculture inputs, gross margin, and yield. It was noted that mean costs of land preparation, seed, intercultural operations, plant protection, irrigation, fertilizer, and post-harvest costs are 4193, 1604, 2870, 2886, 237, 9401, and 5124 PKR per acre for adopters of BMP adopters respectively. Similarly, these mean costs for non-adopters were $3823,1984,3015,3071,267$, 10205 and 5124 PKR per acre respectively as shown in table 2. Costs increase have no significant effect on gross yield especially for land preparation; the results are in correlation with the results of Hassan et al. (2005). The gross margins per acre of adopter of better management practices were 45955 PKR while the non-adopters have 28790 PKR per acre respectively. 
Table 2: Comparative Cost of Production for BMP Adopters and Non-adopters (PKR/Acre)

\begin{tabular}{lll}
\hline Revenue/ Costs & Adopters & Non-Adopters \\
\hline Land Preparation Cost & 4193 & 3823 \\
Seed Cost & 1604 & 1984 \\
Intercultural Practices Cost & 2870 & 3015 \\
Plant Protection Cost & 2886 & 3071 \\
Irrigation Cost & 237 & 267 \\
Fertilizer Cost & 9401 & 10205 \\
Post-Harvest Cost & 5432 & 5124 \\
Total Cost & 26623 & 27489 \\
Average Yield (Mound per Acre) & 24 & 18 \\
Revenue Per Acre & 72578 & 56279 \\
Gross Margins & 45955 & 28790 \\
\hline
\end{tabular}

Source: Authors calculations

The results from the regression model revealed the impact of different agriculture inputs and BMPs on cotton yield. The results showed that the age of the farmer has a coefficient of 0.026 . The coefficients for education are 0.030. Coefficients for water, fertilizer quantity, and quantity of pesticide used are 0.042 , 0.177 , and -0.059 respectively as shown in table 3 .
The dummy variables used of farmyard manure, sowing method, water scouting; and hybrid seed varieties have positive coefficients $0.028,0.074,0.055$ and 0.395 respectively. All the dummy variables including farmyard manure, alternative natural pesticide, water scouting, and hybrid seed variety have a positive significant impact on cotton yield.

\section{Table 3: Factors Affecting Sustainable Cotton Production}

\begin{tabular}{|c|c|c|}
\hline Independent Variables & Coefficients & t-Statistics \\
\hline (Constant) & 1.916 & 2.375 \\
\hline \multicolumn{3}{|l|}{ Farmer Characteristics } \\
\hline Age & $0.026^{\mathrm{ns}}$ & 0.259 \\
\hline Education & 0.030 & 2.192 \\
\hline \multicolumn{3}{|l|}{ Input Variables } \\
\hline Irrigation & $0.042^{\mathrm{ns}}$ & 0.201 \\
\hline Fertilizer & 0.177 & 3.077 \\
\hline Pesticide & -0.059 & 1.657 \\
\hline \multicolumn{3}{|l|}{$\underline{\text { Sustainability Indicators }}$} \\
\hline Farmyard Manure & $0.028^{\mathrm{ns}}$ & 0.502 \\
\hline Sowing Method & $0.074^{\mathrm{ns}}$ & 0.855 \\
\hline Water Scouting & $0.055^{\mathrm{ns}}$ & 0.826 \\
\hline Hybrid Seed Varieties & 0.395 & 4.643 \\
\hline$\overline{\mathrm{R}^{2}}$ & 0.591 & \\
\hline F-Statistics & 33.846 & \\
\hline p-Value & 0.000 & \\
\hline
\end{tabular}


A positive sign for education coefficients shows that education has a positive correlation with the adoption of BMPs. These results are consistent with the results of Dasgupta et al. (2005). A positive sign for irrigation shows that water quantity has a positive impact on the cotton yield and it was significant. The coefficient of fertilizer quantity used is positive and it is insignificant, these results are also consistent with the results of Ashfaq et al. (1993). Pesticide coefficients have a negative sign that shows that there is overutilization of pesticide that causes the plants to bear less fruit by killing useful insects is in practice.

Furthermore, the F value of the model employed in this study shows a value 33.846 generated from the ANOVA Table. It shows that the model was significant. The model also indicates that the production function fits well with the given data set. Therefore, the production function in this study was statistically significant.

\section{Conclusions}

From the empirical results of BMPs adoption rate as a function of socioeconomic, institutional and environmental behavior, concluded that education of the farmers and average farm size of farmers had a positive effect on BMPs adoption rate. The results of the regression model revealed that seed rate, fertilizer application and alternate/skip row irrigation had a positive impact on cotton yield per acre. While the age of farmers, irrigation, water scouting and sowing of pearl millet had an insignificant impact on cotton yield. Farm size and pesticide applications show a negative relationship with the cotton yield. The comparison of the cost of production results for the adopter of sustainable agriculture practices (BMPs) and non-adopters describe that the total cost for nonadopter was greater than that of adopters. Gross margin, as well as the yield of cotton per acre, were higher for adopters of BMPs. Overall, adopters were in a better position to earn reasonable profits by following BMPs. Therefore, strong policy messages arise from these results that the public and private sector should promote sustainable agriculture practices (BMPs) in the study area as well as the other cotton-growing regions.

\section{References}

Abbas, R., Shahbaz, B., Ali, T., Maqsood, M., 2017. Analysis of sustainable cotton initiative in the Punjab; the impact on insect/pest risk management. Journal of Agricultural Research, 55 (1), 280-286.

Ahmad, B., 2001. Researcher's handbook for economic analysis of experimental data. published by the University of Agriculture Faisalabad.
Akudugu, A.M., Guo, E., Dadzie, S.K., 2012. Adoption of modern agricultural production technologies by farm households in Ghana: What factors influence their decisions? Journal of Biology, Agriculture and Health Care. 2 (3), 2224-3208.

Ashfaq, M., Ayyub, C.M., Malik, M.N., Younus, M., Rahim, R., 1993. Effect of $\mathrm{N}$ levels on yield and nitrogen content of okra plant (Hibiscus Esculentus L.). Pakistan Journal of Agricultural Sciences, 30 (3), 84-86.

Awan, S.A., Ashfaq, M., Naqvi, S.A.A., Hassan, S., Kamran, M.A., Imran, A., Makhdum, A.H., 2015. Profitability analysis of sustainable cotton production: A case study of cotton-wheat farming system in Bahawalpur district of Punjab. Bulg. J. Agric. Sci., 21, 251-256.

Byrnes, P., Fare, R., Grasskopf, S., Kraft, S., 1987. Technical efficiency and size: the case of Illinois grain farms, European Review of Agricultural Economics, 14, 367-381.

Cassman, K.G., Pingali, P.L., 1995. Intensification of irrigated rice systems: learning from the past to meet future challenges. Geo Journal. 35 (3), 299 305.

Caswell M., Fuglie, K.O., Ingram C., Jans, S., Kascak, C., 2001. Adoption of agricultural production practices: lessons learned from the US Department of Agriculture Area Studies Project. No. 1473-2016-120785. 2001

Clark, M., Tilman, D., 2017. Comparative analysis of environmental impacts of agricultural production systems, agricultural input efficiency, and food choice. Environmental Research Letters, 12 (6), 064016.

Dasgupta, D., Meisner, C., Wheeler, D., Lam, N.T., Xuyen, K., 2005. Pesticide poisoning of farm workers: Implications of blood test results from Vietnam, World Bank Policy Research, Working Paper, 3624, The World Bank, USA.

Deloitte, A., Tourche, J., 1992. An economic evaluation of soil tillage technologies. Agricultural and Applied Economics, 31, 133147.

Fanning, B., Ferguson, B., 2012. Sustainable production of 100-bushel wheat. In Clay, D.E., C.G. Carlson, and K. Dalsted (eds). iGrow Wheat: Best Management Practices for Wheat Production. South Dakota State University, SDSU Extension, Brookings, SD.

Ghazalian, P.L., Larue, B., West, G.E., 2009. Best management practices to enhance water quality: who is adopting them? Journal of Agricultural and Applied Economics, 41, 663-682.

GOP (Government of Pakistan), 2014. Economic Survey of Pakistan, 2013-2014. Government of 
Pakistan, Finance Division, Economic Advisor's Wing, Islamabad. Pakistan.

Graham, R.C., Hubbert, K.R., Preisler, H.K., Wohlgemuth, P.M., Narog, M.G., 2006. Prescribed burning effects on soil physical properties and soil water repellency in a steep chaparral watershed, Southern California, USA. Geoderma, 130, 284-298.

Hassan, S., Ahmad, B., Bakhsh, K., Ahmad, W., 2005. Profitability and various constraints in potato cultivation. Pakistan Journal of Agricultural Sciences, 42, 3-4.

Isgin, T., Bilgica, A., Forster, L., Batte, T., 2008. Using count data models to determine the factors affecting farmers quantity decisions of precision farming technology adoption. Computers and Electronics in Agriculture, 62, 231-242.

Kouser, S., Abedullah, Mushtaq, K., Mazhar, M., 2006. Role of credit to enhance cotton production in Punjab, Pakistan. Pakistan Journal of Agricultural Sciences, 43, 13-29

Malik, S., Abdullah, M., Javed, I., 2019. Determinants of intra-household income inequality: A case study from rural Pakistan. Journal of Economic Impact, 1 (1), 12-18

Mohanty, S., Fang, C., Chaudhary, J., 2003. Assessing the competitiveness of Indian cotton production: A policy analysis matrix approach. Journal of Cotton Science. 7, 65-74.

Muhrely, T., Frisvold, G., Michell, P., 2009. Adoption of best management practices to control resistance by cotton, corn, and soybean growers. Agricultural and Applied Economics Association, Winconsin.

Mumtaz, H., Malik, M.A., Javaid H., Naseer, M.A.U.R., 2019. Impact of freedom of choice on income: An evidence from Pakistan. Journal of Economic Impact. 1 (2), 64-69.

Naseer, M.A.U.R., Ashfaq, M., Abid, M., Razzaq, A., Hassan, S., 2016. Current status and key trends in agricultural land holding and distribution in
Punjab, Pakistan: Implications for Food Security. Journal of Agricultural Studies. 4(1), 14-27.

Naseer, M.A.U.R., Ashfaq, M., Hassan, S., Adil, S.A., Ariyawardana, A., 2019. Outlook on the global trade competitiveness of Pakistan's mandarin industry: An application of revealed symmetric comparative advantage framework. Outlook on Agriculture. 48 (4), 66-74.

Olayide, O.E., Tetteh, I.K., Popoola, L., 2016. Differential impacts of rainfall and irrigation on agricultural production in Nigeria: Any lessons for climate-smart agriculture? Agricultural Water Management, 178, 30-36.

Sharma, M.K., Bajaj, L., 2010. Recent advances in ginning for lowering cost and improving efficiency. www.icac.org/tis/regional_networks/ documents/asian/papers/ali.pdf.

Tilman, D., Fargione, J., Wolff, B., D'antonio, C. Dobson, A., Howarth, R., Schindler, D., Schlesinger, W.H., Simberloff, D., Swackhamer, D., 2001. Forecasting agriculturally driven global environmental change. Science. 292 (5515), 281284.

Toma, A., Mathijs, G., 2007. To determine the factors influencing the propensity of farmers to participate in the organic farming programs through structured education modeling technique. Journal of Environmental Management, 90, 13851395.

Zheng, H., Li, Y., Robinson, B.E., Liu, G., Ma, D., Wang, F., Lu, F., Ouyang, Z., Daily, G.C., 2016. Using ecosystem service trade-offs to inform water conservation policies and management practices. Frontiers in Ecology and the Environment, 14 (10), 527-532.

Zhong, Y., 2008. Economic analysis of the best management practices (BMPs) in Louisiana sugarcane production. Master of sciences Thesis, Deptt, of Agri. Economics and Agri-Business Louisiana State University, USA. 